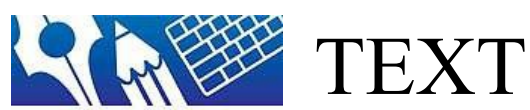

Australasian Association of Writing

Programs
Journal of writing and writing courses

ISSN: 1327-9556 | https://textjournal.scholasticahq.com/

Alternative futures for the creative writing doctorate (by way of the past)

\title{
Paul Magee
}

To cite this article: Magee, P. (2020). Alternative futures for the creative writing doctorate (by way of the past). TEXT: Journal of writing and writing courses, 24(1): 121. https://doi.org/10.52086/001c.17709 


\title{
University of Canberra
}

\section{Paul Magee}

\section{Alternative futures for the creative writing doctorate (by way of the past)}

\begin{abstract}
:
This paper contributes to the project of mapping alternative futures for the creative writing doctorate, by way of deep excavation into the history of scholarly forms. A key aim is to undermine the apparent necessity of an exegetical component to any current creative writing doctoral portfolio. To this end, the paper attempts to think through those traditions of humanities scholarship that have long assumed the presentational forms of novelistic and poetic art. It has a specific eye to works in the post-structuralist tradition, in particular those of Michel Foucault, the scholarly writer whom Georges Canguilhem saw fit to label a 'poet' in the course of examining the doctorate that we would come to know as Histoire de la folie. The paper asks why that naming makes intuitive sense. A philosophical engagement with Anthony Grafton's work on the form and origins of the footnote suggests that normative scholarly texts are ruled by a bifurcation between what is said and the story of how one came to say it, a story offered there at the bottom of the page, or in some other like apparatus or mode. The self-justificatory functions associated with the footnote are minimised in Foucault's and his peers' work, just as they are banished from art itself. In their place, if anything, we find strategies devised for the fomenting of doubt, that have the emotional and intellectual effect of making knowledge the responsibility of the reader. In other words, a form of creative intellectual work without exegetical documentation is not only possible in humanities scholarship, it is a feature of some of the most valorised work in the field. Could we not take our bearings from there?
\end{abstract}

\section{Biographical note:}

Paul Magee studied in Melbourne, Moscow, San Salvador and Sydney. He is the author of Stone Postcard (John Leonard Press: 2014), Cube Root of Book (John Leonard Press: 2006) and From Here to Tierra del Fuego (University of Illinois Press: 2000). Paul is Associate Professor in Poetry at the University of Canberra, where he teaches creative reading.

Keywords: poetics, epistemology, creative writing doctorate, footnotes, Foucault 


\section{The PhD as poet}

On 20 May 1961, in the course of examining the doctoral dissertation that would become Madness and Civilization, Georges Canguilhem named Michel Foucault a 'poet' (qtd in Eribon 1991: 108). I take this fact as the starting point for an investigation into the relationship between scholarly style and knowledge. The nomination itself is not surprising: it makes a certain intuitive sense to call Foucault a poet. What intrigues me is where that intuitive sense comes from, and how it might contour what we expect of our knowledge institutions more generally. For the fact of such a nomination - precisely at doctoral level, with its demand for an original, institutional contribution - suggests that there might be a poetic relation internal to scholarship itself.

It is worth saying from the outset that the shift I have just heralded, from Foucault's case to a general consideration, is not entirely fostered by the literature on him. A tendency to downplay Foucault's fit to scholarship is widespread, and nowhere more so than in relation to the question of his style. So Michel de Certeau refers to 'the allergy his style (more than his theses) provoked among the practitioners of well-established scientific systems', and wonders if it might not have been that allergic reaction that persuaded Foucault, in his last two works, to attenuate the 'exceptional exercise of astonishment' that had been key to the books up until then (1986: 195). Those earlier books are marked, de Certeau writes, by constant 'turnabouts, which, disturbing the constituted domains of knowledge, even the most authoritative (even Marx, even Freud), generate new ways of thinking' (1986: 195). Yet de Certeau's references to 'the practitioners of well-established scientific systems', those 'lieutenants of meaning' and 'schoolmasters of authority' (195) who would apparently prefer the latter style, seem somewhat undermined by the fact that those later works have never achieved the massive authority of History of Madness (2006 [1961]), Discipline and Punish (1977) or The History of Sexuality, Part 1 (1978) (Rajchman 1991: 7). The institutionally preferred Foucault is the disturbing one, the poet who works with 'astonishment' (de Certeau 1986: 195).

But Foucault himself downplayed his fit to scholarship, on the same grounds of style. Consider the 1983 interview in which he was asked by Stephen Riggins about the relation between '[his] kind of philosophy and the arts in general' (qtd in Lamb 2005: 44). Foucault responded that he was 'not in a position to answer'; for his work was not that of 'a good academic', but rather 'related to what you could call aestheticism, meaning transforming yourself' (qtd in Lamb 2005: 44). I will turn to this idea in a moment, merely noting in passing the paradox that one who is not 'a good academic' (44) could achieve such widespread academic uptake.

Judith Butler adds another dimension to the discussion in her lecture 'What is Critique? An Essay on Foucault's Virtue' (2001). Hers and de Certeau's essays are among the relatively few texts (see also Lamb 2005, Halperin 1995 and Rajchman 1991) that attempt to take the measure of Foucault's massive style. And yet Butler's analysis, too, seems curiously opaque on the links between that style and the extraordinarily wide reception of the works it contours. There she offers a close reading of a passage in Foucault's 1978 lecture 'What is Critique?' in which Foucault speaks of an 'originary freedom' (1997: 72) and shortly thereafter adds, as if in another voice of his, a refusal either to accept or deny such a freedom's existence. But that initial invocation of the concept has already served, Butler comments, as a way for Foucault's readers to 'relive its resonances, and know its power' (2001: 11). In this polyvocal fashion,

TEXT Vol 24 No 1 April 2020

General Editor: Nigel Krauth. Editors: Julienne van Loon \& Ross Watkins 
a certain freedom is exemplified, not by the reference to the term without any foundational anchor, but by the artful performance of its release from its usual discursive constraints, from the conceit that one might only utter it knowing in advance what its anchor must be. (Butler 2001: 11)

As in many a close reading, there is some suggestion here as to how and why we as readers respond to the author's moves.

It is nonetheless the case that Butler, along with the majority of the other commentators I have just mentioned, generally eschews close readings of passages from his books and lectures, even while commenting on Foucault as stylist. The tendency is rather to seek answers to these questions through a deep engagement with the explicit positions Foucault himself took on matters of intellectual style. I am referring especially to the discussion Foucault initiated in the introduction to The Use of Pleasure (1992), where, as in that more or less contemporaneous interview with Riggins, Foucault indicated that the aim of his writing was his own self-styling, 'through the practice of a knowledge that is foreign' (qtd in Butler 2001: 4) to him . Now this late Foucauldian linking of the poetic to the 'practice of the self' in its encounter with difference, much more than to the production of an object calibrated (even oppositionally) to disciplinary or even aesthetic demands, is certainly rich. The stance seems keenly related to poets' actual reported statements about their approaches to composition (Magee 2016), to confine my appreciation to its relevance to art. But inasmuch as a focus on the production of Foucault's style makes his nomination as 'poet' an effect of his own striving (Butler's word virtue is revealing), it turns us away from the question that intrigues me here concerning why poetic works thus (or otherwise) produced achieve such huge readership among scholars. What is it about the surfaces they present that generates such wide and ongoing influence over distinct and even seemingly unrelated fields?

I hasten to add that in undermining Foucault's exceptionality over these opening paragraphs, I do not intend to diminish his radicalism. My intention is to amplify it. What I want to suggest is that Foucault's style, considered in the context of such a massively infiltrating body of work, might be evidence of a more general radicalism, one dramatically internal to scholarship and available for use.

It is certainly true that the broadly poetic and novelistic readings of Foucault cited from de Certeau and Butler above, with their intimations of Aristotle ('astonishment') and Bakhtin (polyvocality) respectively, could illuminate, and also raise questions about, numerous other works. I am referring to those traditions of scholarly writing that have long assumed the presentational forms of poetic and novelistic arts, without, for all that, being repudiated as insufficiently scholarly. To the contrary, they often become canon. I have in mind texts like Frantz Fanon's Black Skin, White Masks (1970), Luce Irigaray's This Sex Which is Not One (1985), Jacques Rancière's The Ignorant Schoolmaster (1991), Catherine Clément's Opera, or the Undoing of Women (1988), Caroline Walker-Bynum's Jesus as Mother (1982), Hubert Fichte's The Gay Critic (1996), Krim Benterrak, Stephen Muecke and Paddy Roe's Reading the Country (1984), Alphonso Lingis's Abuses (1995), and more. I have in mind that proliferation of creative scholarly forms emerging from, or rediscovered during, post-structuralism, a tradition almost hegemonic in the humanities by the start of the 1990s, when I found myself reading into it as a first-year anthropology student, having books like Michael Taussig's Shamanism, Colonialism and the Wild Man: A Study in Terror and Healing (1986) in my hands, and getting ideas. Then reading Benjamin. 
Let me crystalise these issues on him. Take the following lines, from Benjamin's 1929 review essay 'Surrealism, or the Last Snapshot of the European Intelligentsia', an essay aimed at taking the measure of the then new movement:

At the centre of this world of things stands the most dreamed-of of their objects, the city of Paris itself. But only revolt completely exposes its surrealist face (deserted streets in which whistles and shots dictate the outcome). And no face is surrealistic in the same degree as the true face of a city. (in Benjamin 1986: 182)

This is spellbinding, but it brings a curious question to mind as well: within what paradigm is this passage recognisably scholarly? I think few would have trouble with the label poetic. But how do we explain the quantity of humanities texts that quote these and not-dissimilar lines from Benjamin as some kind of canonical authority ('Benjamin argues ...'; 'Benjamin says ...')? This is no small matter; the well-known Thomson Reuters survey of 2007 Humanities citation data (qtd in Times Higher Education 2009) had Benjamin as the twenty-fifth most cited author (Lacan thirty-third, Deleuze twelfth, Foucault number one). Is this same, widespread practice of citing Benjamin in the humanities separable from the fact that his writing is so intuitively recognisable, like Foucault's own, as poetic?

What is humanities scholarship, such that it cannot only accept but even celebrate, and centre itself upon, outlier texts like Discipline and Punish (1977), or Benjamin's The Arcades Project (1982)? More polemically put: rather than treating creative writing as a foreigner to the academy, that somehow requires the sanction of an exegesis to be allowed in, can we not explore the possibilities that follow from the existence of a highly valorised aesthetic mode within scholarship itself?

\section{Normative scholarly style}

To understand the textual practices of radical outliers like Benjamin, Irigaray, Fichte and Foucault, we need, it seems to me, to have some model of the normative practices from which they depart. Ideally such a model would have explanatory power beyond the question at hand as well. It strikes me, for instance, that our model should have sufficient power to illuminate something that is otherwise somewhat opaque, viz why we locate humanities academics, given their predominantly qualitative methods, within the same institutions as scientists. How do historians, ethnographers and literary scholars style their contributions to knowledge, what is customary in our general approach to it, such that the institutional collocation of scholar and scientist in the modern university somehow makes sense? But even regardless of such larger questions, a model of normative scholarly style will surely put us in a better position to address the issue of exceptional practitioners like Foucault, Lacan and Deleuze.

My way in will be through a philosophical engagement with intellectual historian Anthony Grafton's considerations on the humble footnote, that hallmark of traditional humanities style. It will transpire that this device is directly linked to the stylistic perspective that seventeenth century natural philosophy, later to be labelled science, brought to the world. That perspective is absent from novels, absent from poems. I will consider those seventeenth century origins in some detail, with final focus on the contributions of René Descartes, on the grounds that Descartes describes with startling clarity 
the way we as scholars and scientists, even now, normatively style our approach to knowledge. Descartes illuminates things in this fashion because his project was to proselytise for what was at the time a still controversial and even repudiable point of view. As such, Descartes helps us to grasp that a scholarly monograph is - at least typically, and in what regards - fundamentally different to a novel. The better to take advantage of the resources at hand. For that is my ultimate aim in this writing, to discover scholarly writing's potential identity with literature, that elusive quality that comes to us fully-fledged in Michel Foucault, the poet, who is, by the same token and in one and the same work, historian of the present. But what then is the norm from which he departs? I am going to suggest that it is autobiography. Our scholarship is normatively linked to an autobiographical voice.

The Footnote, A Curious History was first published in English in 1997. The book is something of a detective story. It tries to answer two questions: firstly, what does the historian's footnote do?

Secondly, where does it come from? The answer to the second of these questions arrives on page 206. But Grafton gives us clues to both questions from his first pages, which open with a startling but obvious proposal: the footnote tells a story. More specifically, it tells 'a secondary story, which moves with but differs sharply from the primary one' (Grafton 1997: 23), that primary one being the story of the past you find in the body of the text itself. What is more, that secondary story does not derive in any direct way from what would seem its obvious predecessor, the marginal glosses that in the Middle Ages provided exegesis on sacred manuscripts. Medieval glosses on patristic and other holy works served, Grafton comments, to 'buttress a text which draws its main authorization from ... the fact that its author was divine, or more often, divinely inspired' (1997: 31-32), or from the fact of its great antiquity. Glosses were thus presented 'as intermediaries between a text considered to be of eternal value' (32) and those mortal souls in the present, whose capacity for any such eternal truth was 'necessarily limited by immediate needs and interests' (Grafton 1997: 32). Glosses helped a reader, from his or her specific point in time, to get closer to that divine source. Now the contemporary historian's footnotes certainly resemble such glosses 'in form':

But they seek to show that the work they support claims authority and solidity from the historical conditions of its creation [...] To do so they locate the production of the work in question in time and space, emphasizing the limited horizon and opportunities of its author, rather than those of its reader. (Grafton 1997: 33)

For the 'secondary story' conveyed by the modern historian's footnote serves to reveal the story of the author's research: it tells what archival texts he or she read, and what scholarly debates he or she considered, so as to arrive at the substantive statements in the text, which are of course a story in their own right, the primary one.

An amusing aside serves to cast light on the nature of this secondary story. There Grafton mentions the widespread tradition of heading articles with long, prefatory footnotes 'in which the author thanks teachers, friends and colleagues' (1997: 7); he adds that often what such notes describe is 'something much more tenuous, the group of those who the author wishes had read his work, offered him references or at least given him the time of day' (7). Grafton's purpose, in proceeding to label such prefatory notes a form of 'scholarly autobiography' (7), is humorous, and his study swiftly moves on. In fact, this phrase names, albeit as a passing joke, what Grafton's study has to illuminate of the footnote as a stylistic phenomenon more generally. For what emerges from these incisive analyses of the modern requirement that 'history should tell the double story of the historical past and the historian's research' (Grafton 1997: 67) is that the latter tale, moving underneath the body of the text,

TEXT Vol 24 No 1 April 2020 
is a profoundly autobiographical one, not just at the moment of prefatory, and perhaps hopeful acknowledgements, but all through. I have followed a valid method, and so have the right to say $\mathrm{x}$.

The fact that elements of self-justification pertain to the footnote emerges repeatedly from Grafton's analysis. He refers to graduate students 'peppering' their pages with footnotes 'to show that they have put in hours of hard work in archive and library' (Grafton 1997: 5), adding that for professional historians more generally the use of footnotes amounts to 'the bold assertion of one's right to take part in a learned dialogue' (6). Yet such boldness is, Grafton underlines, always attenuated by the fact that any of one's footnotes can be called to account. For if contemporary historians' 'two complementary tasks' (Grafton 1997: 4-5) can be boiled down to the twin-demand that they 'examine all the sources relevant to the solution of a problem and construct a new narrative or argument from them,' (4-5) it is the footnote that 'proves that both tasks have been carried out'(4-5). Now the practice of footnoting has, of course, many contemporary functions, from character assassination (Grafton 1997: 8), through to social networking (Grafton 1997: $13 \mathrm{fn} .23$ ), including not just clarification but digression as well, and many of these are thoroughly, indeed delightfully, excessive to any rendering of accountable selfhood. Grafton is very interested in that diversity. But I think we can nonetheless say that the function the device tends towards, that without which a footnoted article runs the risk of being labelled mere opinion, is to allow for demonstration of the probity of one's conduct as scholar. I would suggest that elements of confession are detectable here too, were it not that confession, in the Catholic context, tends to imply subsequent absolution. What we have in the footnote is rather a submission of self for judgement, which might go either way.

As for Grafton's interest in all this: his claim that once we begin to write with footnotes 'historical narrative tells a distinctively modern, double story' (1997: 23) has a polemic purpose. This emerges at the very end of the book, through a rather vague reference to the fact that in 'recent years, some scholars have argued, influentially, that history is nothing more than a form of imaginative literature a narrative like a novel' (Grafton 1997: 231). Below this comment one discovers a curious footnote ('See eg') to an article, the title of which promises critical appraisal of the theory of tropes propounded by a certain North American historian:

\section{See e.g. A. Momigliano, 'The Rhetoric of History and the History of Rhetoric: On Hayden White's Tropes', Settimo contributo alla storia degli studi classici e del mondo antico (Rome, 1984), 49-69. (Grafton 1997: 231)}

Recalling White's famous undermining of historical objectivity on the grounds that the historian, just like the creative writer, employs considerable 'invention' in plotting the way his version of the past will be told (White 1973: 6), it is hard not to detect a considerable sub-textual dig here. For White, as Grafton goes on to imply in the body of his text without ever naming him there, has failed to see the clear gulf separating a Gibbon from a Dickens, a Grafton from a DeLillo. What Dickens and DeLillo's novels lack - epistemologically speaking - is the accompanying secondary story, a story that is autobiographically framed to convey a set of accountable actions any other might perform in its author's shoes, so as to arrive at the same result.

This initial foray into the analysis of the footnote already has the capacity to cast some light upon the question of a normative scholarly style. Novels, just as poems, are not the same as history books. As Grafton helps us to see, such artworks lack a secondary story, the one conveyed through the author's

TEXT Vol 24 No 1 April 2020 
repeated autobiographical gestures off the page to his or her lived actions as researching subject. For in literature, as in the arts in general, 'the end product ... has primacy, and how it is achieved is left in mystery' (Parr qtd in Strand 1998: 49). Whereas a history book makes 'how it is achieved' explicit, via the secondary narrative provided in the footnotes. In the absence of that sort of autobiographical apparatus, a historian's narrative is indeed hard to distinguish from fiction. This is a charge that has been tabled against Foucault (Ginzburg qtd in Megill 1987: 132; Anderson 2011: 140), whose footnotes we shall come to in due course. But let's stay with Grafton's ideas for the moment, the better to round out our sense of the normative contours of scholarly style.

This initial summary of Grafton's work on this historian's footnotes immediately begs questions about the broader applicability of his analyses beyond the discipline of history, and indeed beyond the footnote itself. It is, after all, no great leap for me to assert that the in-text references, which I use in this article in lieu of the footnotes a historian would use, have a similar autobiographical function, serving as they do to bifurcate my utterance into the argument I make and the story of how I came rightfully to make it, a story detailed in terms of the sources I list as having read. But will one find this same, 'distinctively modern, double story' (Grafton 1997: 23) in the research reports of disciplines further afield, for instance, in medical science, or engineering? To see that one will, consider the implications of Dennis Strand's acute observation that scholars' and scientists' papers, articles and monographs serve as 'proxy' for their 'overall research activity', and generally do not count as research outside that relation:

The publication is not the research but simply the outcome of the research process. The research occurs in the laboratory, the field, the studio, the library, at the computer terminal, in the workshop and may have extended over months, even years, before it is made public. (Strand 1998: 56)

Strand's observation reminds us of the necessity to point, in one's scientific paper, as much as in one's humanities article or monograph, to the genuine, lived-through investigatory processes that serve to give that document its status as research. One presents one's field or lab or library findings, and one accompanies them with an autobiographical account of how one justifiably arrived at them (see Hoffmann 2010: 144 for an explicit link between the autobiographical rendering of account and the Method component of the Introduction, Method, Results and Discussion [IMRaD] template followed by the majority of contemporary scientific papers; see Gross et al 2002, for the historical emergence of the IMRaD style). Which is to say, scientific writing tells 'a distinctively modern, double story' too (Grafton 1997: 23). In fact, it has to. We do not actually allow knowledge claims on the grounds of their objectivity. As AJ Ayer put it, in his discussion of our language use around the matter: 'If someone reaches a true conclusion without appearing to have any adequate basis for it, we are likely to say that he does not really know it' (1962: 33). Someone, for instance, who was 'fully persuaded of a mathematical proposition by a proof which could be shown to be invalid' would not 'be said to know the proposition, even though it was true' (Ayer 1962: 31). What this observation highlights is that the scholarly pretence of de-authoring one's knowledge claims (It is the case) is little more than window-dressing. We do not actually allow knowledge claims to be propounded solely on the grounds that something is the case not even when we know it truly is the case. Indeed, the question is only peripherally about 
objectivity and much more about the drama of the subject. The real scholarly and scientific imperative is that the knower has followed a process that grants him or her the right to know, and can demonstrate that, autobiographically, via footnotes and other such apparatuses.

The second implication I want to draw from Strand's comments on the knowledge-report's proxy status goes to the very character of the subject whose justified past actions any normative scholarly discourse will necessarily represent (whether through its author's first person singular self-report on their conduct in the body of the text; or through the very act of making a footnote or in-text reference - which conventionally implies that one has diligently read the materials there referenced; or through the act of tabling the figure that validates the statistical significance of one's studywhich, again, conventionally implies that one has engaged in the calculations that led to it; or however). It is that the I who followed all these processes (I have followed a valid method and so have the right to say $\mathrm{x}$ ) is the same as the one now telling you about them. There is a presumption of diachronic consistency between that past I running the lab, or performing the fieldwork, or producing the literature review, and the present I now relating the results of these procedures. We might even say that normative scholarly writing bears an implicit demand that we trust in its author's consistency over time. Actually, there is a presumption of synchronic consistency to the I that reports as well, a presumption of immediate self-sameness, in spite of the threat that any such I might in the very moment of its reporting be multiply fractured and even split between the one professing knowledge and some other emerging through the speech of that I as well. For who does not make slips of the tongue or pen? All of these errant selves get collapsed into the voice indicating or implying, in footnote, exegesis or elsewhere, that I have followed a valid method and so have the right to say $\mathrm{x}$. Jacques Lacan nails it with brutal precision:

The myth of the ideal I, of the I that masters, of the I whereby at least something is identical to itself, namely the speaker, is very precisely what the university discourse is unable to eliminate from the place in which its truth is found. (2007: 63) [1]

It is an I with which any other can identify. What is more, it is this same I-cratic voice - 'the naïvely self-confident or stubbornly obtuse unity of a smooth, pure, single-voiced language' (Bakhtin 1981: 327 ) - that we critique whenever we find it dominating the imaginative possibilities of our artworks. It is also the voice of the creative writing doctoral exegesis, that little-loved (eg Candlin 2000; Biggs \& Büchler 2010: 87; Magee 2012a) accompanying essay that has acted to make a creative artist's doctoral submission institutionally accountable.

\section{Descartes' critique of history-writing}

Grafton's book answers two questions, one concerning the function of the footnote, the other its origins. I have focused on the first of these questions to this point. It is worth highlighting that Grafton does not go as far as me in equating the footnote with a species of moral autobiography, nor does he extend his findings to other humanities disciplines, to say nothing of the sciences. And Grafton does not quote Lacan. As indicated, my purpose here is to philosophise with, rather than simply rehearse, the contours of Grafton's claims. But it is intriguing, all the same, to see how his answer to the second of his opening questions - where does the footnote come from? - corroborates the extrapolations I have made to this point. For Grafton will suggest that the modern-style footnote arose as a response to that thinker who militated for the pre-eminence of the properly trained, individual 'I' in validating any

TEXT Vol 24 No 1 April 2020 
form of knowledge whatsoever. More specifically, it arose as a response to Descartes' attack on history-writing, as a genre indistinguishable from fiction.

But how does Descartes come into the picture? As stated above, it does not happen until page 206 (Grafton 1997). Grafton's sleuthing for the origins of the footnote, and thereby a recognisably modern form of historical scholarship, first focuses on Leopold Ranke in the nineteenth century (1997: 34-93), only to discover that whatever of the 'distinctively modern, double story' (1997: 23) one finds in Ranke was there in Edward Gibbon's pervasively footnoted volumes as well (1997: 94-121). Grafton's narrative pushes back in time to find a predecessor to Gibbon but has clearly overshot the mark in next landing on Jacques-Auguste de Thou (1997: 133), whose massive Historiae Sui Temporis had its first complete edition in 1620. For although the Historiae were based on vast and discriminating documentary research, it is clear that de Thou had no wish to disfigure his page with any sort of apparatus. He, along with other Renaissance historians, wanted to emulate the Greek and Roman classics in this glossless regard, as in many others (Grafton 1997: 141). The footnote, as a normative device for ensuring a historical writing's validity, is post-1620.

Now Herodotos, to put one of the classics de Thou wished to emulate on the table, can certainly be said to have personalised history-writing: 'I shall begin ... with the man whom I myself have known to be the first to inflict harm and injustice on the Greeks ... Croesus' (qtd in Cartledge 1993: 31). Herodotos' 'characteristic emphasis on the first person pronoun' truly did, as Paul Cartledge points out (1993: 31), announce a whole new form of history writing to the Classical world, a recognisably investigative one, that stood in stark contrast to the depersonalised chronicles preceding his writing. And just as narratologists talk in terms of the narrativity of a text, which can be weak or strong, we might say that Herodotos' text, rather like de Thou's, has accountability, but only weakly so. Their texts' accountability is weak when compared to Gibbon's The History of the Decline and Fall of the Roman Empire (1776-88), which features the sort of paragraph-by-paragraph self-justification we have come to require: the sort that leaves a trail for anyone else to follow up and sound.

A shift towards a regime of greater personal accountability is a useful rubric for nutting out what is at stake in the historical emergence of normative scientific and scholarly styles, over these same centuries. For when Grafton detects a surer forebear to the modern footnote in the pro-Catholic and pro-Protestant historians of the post-Reformation period (Ulrich Von Hutten, Flacius Illyricus, Cesare Baronio, et al) than in the secular, and even highly investigative ones like de Thou, what he is responding to is the stronger presence of authorial accountability on the very surface of their work. These sectarian 'controversialists and believers' eschewed 'the neat classical prose of the political historians' in favour of 'a mixture of technical arguments and supporting documents, the latter quotedverbatim in the text proper' (Grafton 1997: 156). From our perspective, such historians lacked a 'clearseparation between text and apparatus', but they nonetheless had a far stronger sense of the need to undergird the story they were telling with demonstrations as to the probity of the process leading to it,than humanists like de Thou (Grafton 1997: 188). After all, the controversialists' whole drive was to see that primary story prevail.

The footnote's real inventor, Grafton at length reveals, came a century after those ecclesiastical forebears, though still sixty years before Gibbon. It was Pierre Bayle, author of the equally controversialist Historical and Critical Dictionary, which was initially published in 1697. Bayle, Grafton notes, 'described himself wonderfully, as a real protestant - the sort who on principle protests against everything' (1997: 192). Bayle's Dictionary gave entries for persons and places throughout

TEXT Vol 24 No 1 April 2020 
history, while the notes to each entry served to justify the claims in the entries, in terms of the document trail leading him to them. As such

Bayle devised and defended a double form of narrative: one which both stated final results and explained the journey necessary to reach them. Pressed by a thousand enemies, Catholic and Protestant, enraged at the reign of error in a thousand books, and unsupported by any institution, Bayle had only the authority of his own scholarly workmanship to rely on. (Grafton 1997: 200)

So he made it public.

Yet if Bayle is inventor of the footnote, his originality in this regard is somewhat undermined in Grafton's history, and not simply because Bayle's focus on rendering account for his own actions as historian was presaged in the writings of the ecclesiastical controversialists I have just mentioned. More than anything else, Grafton charges Bayle's invention of the footnote to the fact that he was 'a student of the new philosophy of Descartes' (Grafton 1997: 191). This is so much the case that Grafton titles the chapter in which he treats the matter 'The Cartesian Origins of the Modern Footnote'. For an immediate insight into this claim as to Descartes' virtually authoring role, consider René Descartes' strategy of forging natural-philosophical foundations for knowledge by arguing that only the authority of an individual I's rational observations, regardless of all prior tradition, is sufficient to rely on in matters of truth. Compare the autonomy evoked above: Bayle, Grafton writes, made provocative historical assertions with 'only the authority of his own scholarly workmanship to rely on' (1997: 200). The device of the footnote served, in true Cartesian fashion, to transform that solitary fate into the very indice of accountability.

Specifically, Grafton argues that it was Descartes' 'withering critique' of history-writing, in the first chapter of the 1637 Discourse on the Method of Rightly Conducting One's Reason and Seeking the Truth in the Sciences, that sparked Bayle's invention (1997: 206). That chapter's general demolition of medieval and classical knowledge includes an attack upon the way 'even the most accurate historical accounts' (Descartes 1968: 31) will try to provide agreeable precepts much more than realistic observations. Historians 'almost always leave out the basest and least illustrious circumstances'(31), with the result that those who model their behavior on such texts 'risk falling into the extravagances of the paladins of our novels' (31). According to Grafton, Descartes' attack upon the parallels between history-writing and fiction drove seventeenth century historiography to attempt a whole range of curious remedies, including 'quasi-geometrical chains of deductions' (Grafton 1997: 206) and computational approaches to 'the decrease of authority over time' (206). But it was Bayle who ultimately met the challenge, by creating 'the double form of the double narrative, as one that would make explicit, just as the Cartesian Regulae did, that each argument followed from all the relevant evidence' (Grafton 1997: 206). Bayle met the challenge by providing a device that might autobiographically render account for the story in the body of one's text, and so serve to distinguish the whole from a romance like Orlando Furioso. He made the humanities scientific.

With these Cartesian origins we are, I suggest, right at the forging point of that scholarly style that persists into the present, with its 'distinctively modern, double story' (Grafton 1997: 23), the very thing informing our otherwise very strange decision to require that the creative arts doctorate comprise both artwork and scholarly exegesis. Already by 2004, Julie Fletcher and Allan Mann were writing that 'contestation and debates' over the possible form of such a doctorate appeared 'to have

TEXT Vol 24 No 1 April 2020

General Editor: Nigel Krauth. Editors: Julienne van Loon \& Ross Watkins 
been resolved by university policy developments that had established the "creative work plus exegesis" model' (Fletcher \& Mann 2004) (compare Strand, for an earlier era's alternatives, which may become ours again in the future). We are almost ready to consider Foucault, his repudiation of any such academic accountability - as in the following, profoundly anti-academic refrain:

Do not ask who I am and do not ask me to remain the same: leave it to our bureaucrats and our police to see that our papers are in order. At least spare us their morality when we write. (Foucault 1972: 17)

We are almost ready to consider what a Foucault or a Benjamin offer in that accountable subject's place, with the paradoxical result that their work can be considered not just some species of art, but the pinnacle of scholarship itself.

\section{'[T]he simple reasoning of a man of good sense concerning things which he meets'}

But first, the thing that doesn't add up in Grafton's account. For on the one hand, and in the most beautifully poised way, this linking of the footnote to Descartes yet again neatly undercuts Hayden White's influential work. To flesh out Grafton's allusion to White's 1973 Metahistory: The Historical Imagination in Nineteenth-Century Europe, consider the way White supports its claims as to 'the nonscientific or protoscientific nature of historical studies' (1973: 428) by pointing out that neither in history-writing, nor 'among the social sciences in general' (429), has any single 'technical language by which to communicate findings ... succeeded in carrying the day' (429). White contrasts the polymorphousness of style that apparently holds among historians, to 'the way that mathematics and logic' (429) became the collective convention for communicating knowledge 'in the physical sciences from the time of Newton on' (1973: 429). Scholarly historians' failure to achieve a formally unifying style, in the manner of the natural philosophers of the seventeenth century, is for White, one more measure of the indistinction between their writing and fiction. Grafton suggests he look beneath the body of his text.

But inasmuch as this diagnosis of the footnote's 'Cartesian Origins' puts paid to one of the most popular of recent problematisations of academic history-writing, it by the same token begs a huge question, one Grafton leaves frustratingly unanswered. Recall Descartes' resolve, as he formulates it in chapter five of Discourse, 'not to accept anything as being true which did not seem to me more clear and certain than had previously the demonstrations of the geometers' (Descartes 1968: 61). Recall that same Descartes' triumphant conclusion to the fifth of his Meditations, that he can, on such grounds, know with certainty 'the entirety of that corporeal nature which is the object of pure mathematics' (Descartes 2006: 40). Let's focus on the relation of these quotations to Bayle's innovation in devising a scientific device for historians. For at this point we surely have to ask ourselves how the autobiographical mechanism of the footnote could ever lead to geometric or any other form of mathematical certainty? Can the historian's footnote, I-bound device that we have foundit to be, really meet on the same terrain as the 'object of pure mathematics' (2006: 40)? More pertinently, how could Bayle have ever thought it might? How could anyone at the end of the seventeenth century have imagined that a set of in-essence autobiographical attestations to the probity of a scholar's process might bring their findings even remotely close to the quantitative truths sanctioned as certain by Galileo, Descartes, Huygens, Newton et al? 
One answer is that the seventeenth century's 'mathematization (geometrization) of nature' (Koyré 1943: 404) pivoted upon the assumption of the very subjectivity the footnote enshrines. That mathematization would not have made sense as a register of certainty, were it not accompanied by an elevation in the epistemological status of the I, as the agency observing, and finding something beyond doubt there. For prior to that, every I in the world might find it practically incontestable that $\sqrt{ } 16=4$ (an equation in use from at least the Babylonian epoch) without that state of almost universal agreement having any necessary impact on their conception of truthful knowledge at all. Quantitative truths could be wrong, no matter how many people felt compelled to hold them. As Descartes states in the Meditations, 'may I not [...] be deceived every time I add 2 and 3 or count the sides of a square, or perform an even simpler operation, if that can be imagined?' (Descartes 2006: 11). It was the epochal shift away from a prevailing, radical scepticism as to human powers of understanding viz a viz the Creator and His Creation, towards a trust in the methodologically disciplined I's observations of phenomena, that was uppermost in contemporaries' minds. That shift in perspective was pivotal to any mathematisation per se, absent which numbers bear no foundational truth at all.

These are of course huge claims and cannot be sufficiently argued here (for some of the groundwork, see Glynos 2002 and Magee 2014). What I can do, however, is point to a passage in Descartes' 1637 Discourse on the Method that offers an explicit link between the natural philosopher's focus on phenomena whose 'certainty and self-evidence' (31) seems, as in pure mathematics, to be there on the very face of things, and the amplified role this implies for that knowing subject's I. Descartes is not, pace Paul Valéry (1948: 4), solely responsible (see Condren et al 2006 for a useful corrective) for this shift in knowledge's perspective, from the gamut of traditionally sanctioned past authorities to that of the pared-back I, which latter point of view we will come somewhat fallaciously to term 'objectivity', the point of view enshrined in our mathematical foundationalisms, our footnotes, and creative writing exegeses. But Descartes does epitomise, and indeed illuminate, the shift. As such, he helps us to see that Grafton is correct: Descartes, the geometer, does indeed lead to the footnote, and whatever trust we place in it. Our trust is in the probative value of its perspective. It offers us a space that seems beyond fiction, one from which fictions can be known and mastered.

The illuminating passage I have in mind comes in chapter two of Discourse, in the course of Descartes' famous description of a meditation he had during the course of his travels. This follows the commentary he gave on his education at the Jesuit school of La Flèche in chapter one, a commentary that included the critique of history-writing cited above, the doubts he formed at La Flèche as to the validity of any of the various available knowledges other than mathematics, and the way he eventually 'abandoned the study of letters altogether' (Descartes 1968: 33) and took to travel. Subsequent chapters will see him settling in Holland, will describe the cogito he performed there, along with the proof of God's existence, and will explain the way that proof in turn serves - for a perfect being could not deceive him on this - to validate the idea that 'everything we conceive very clearly and distinctly is true' (Descartes 1984: 1; 130); upon which the Discourse will turn to the various findings these proofs led Descartes to, including his theory of the light of the sun and the stars, and the circulation of blood. [2]

Chapter two elucidates the sort of subject who is capable of trusting in his own observations in this manner, above and beyond all of the traditionally superior claims of established authorities and their commentators. It opens, as is well known, with Descartes finding himself at age twenty-three in 
Germany, 'in a room heated by an enclosed stove, where I had complete leisure to meditate upon my own thoughts' (Descartes 1968: 35). What follows is intimately related to the subsequent genesis of the footnote.

It occurred to him in that room, Descartes writes, to consider that 'often there is less perfection in works composed of several separate pieces and made by different masters' (1968: 35) than there is in those in which 'only one person has worked' (35). A building that a solitary architect has brought into being is, for instance, usually better than 'those that several architects have tried to put into shape, making use of old walls which were built for other purposes' (35) Similarly, an old city that has grown from a village through the accretion of continual new buildings in different styles gives the impression that it is 'more the product of chance, than that of a human will operating according to reason' (35). Descartes proceeds to describe how his thoughts then turned to 'the peoples who were formerly half savages, and who became civilized only gradually' (36). He reasoned that such people

could not be so well organised as those who, from the moment at which they came together in association, observed the basic laws of some wise legislator; just as it is indeed certain that the state of the true religion, the laws of which God alone has made, must be incomparably better ordered than all the others. (Descartes 1968: 36)

'And, to speak of human things', Descartes continues, what worth there was in Spartan society can surely be attributed to the constitution handed it by Lycurgus, for 'having been invented by one man only' (36), its laws 'all tended towards the same end' (36). At which point knowledge comes into the picture:

And so, I thought that the knowledge we acquire in books, at least that based upon reasoning which is merely probable and for which there is no proof, being composed and enlarged upon little by little by the opinions of many different people, does not approach the truth as closely as the simple reasoning of a man of good sense concerning things which he meets. (Descartes 1968: 36)

So, Descartes introduces his plan to demolish all the received ideas of classical and medieval knowledge, 'once and for all to be rid of them in order to replace them afterwards either by better ones, or even by the same, once I had adjusted them by the plumb line of reason' (Descartes 1968: 37) - ie once he had adjusted them, irrespective of all prior authority, to the reasoning of his solitary I. The chapter proceeds to enumerate the rules that will guide him in this mission, right up to and beyond the questioning of his own existence in chapter four. But let us arrest that movement toward justifiable knowledge here, in the isolation and elevation of the I it presupposes. Descartes' image of the thinker as autocratic, sacred law-giver is striking and also, I will suggest, disturbingly modern. Consider, for an immediate, uncanny parallel, Grafton's description of the personalised perspective of the modern footnote, which acts to 'locate the production of the work in question in time and space, emphasizing the limited horizon and opportunities of its author' (Grafton1997: 33). Descartes, in chapter two of Discourse, is ushering just this perspective in, through these metaphors, but equating it not with limitation so much as with mastery. God himself looks upon the world from this first person singular perspective! It is as if the desacralisation Grafton charts in the passage from scriptural gloss to secular footnote is here, in these founding moments of the latter perspective, revealed as a new sacralisation in its own right: our God of knowledge is the I, the 'simple reasoning of a man of good sense' (Descartes 1968: 36) in the face of the phenomena 
beforehim.

Nor should we forget the revolutionary dimensions of Descartes' governmental analogies, perhaps in spite of himself. For if that same 'simple reasoning of a man of good sense' is accorded monarchical power here, monarchy is brought down to earth in the process (Jay 1993: 59, fn.153), made the potential possession of any one self bold enough to follow Descartes' example - an example that has something of the divine to it, and no little faith in the idea that reality ultimately has a clear logic to it, as well.

It is a position medieval science could not bring itself to accept.

To a nominalist, the Copernican system would be an inference transcending experience. Its greater simplicity and explanatory power would not have justified the momentous step of conferring reality upon the system. God could have made this contingent world complex rather than simple. (Grant 1962: 215)

Grant adds that many of the arguments for 'a diurnally rotating earth' (212) were actually 'commonplace in scholastic discussions' (212). Nicole Oresme, for instance, hypothesised it in the fourteenth century, adducing evidence. But he also hypothesised that the earth was immobile. Indeed, he held both hypotheses (Grant 1962: 211). For Oresme, as for the hugely influential Franciscan philosopher, William of Ockham (1290-1349), a hypothesis amounted to 'an accounting for the phenomena' (Grant 1962: 214), which cannot ultimately pierce through to their reality, the latter being beyond our powers to know (214) [3]. So why not hold two contradictory hypotheses concurrently?

Again, what Descartes refers to as the 'simple reasoning of a man of good sense' (1968: 36) could only serve as foundation for claims about the world, and so outweigh the competing claims of tradition and divine revelation, once notions as to the world's unknowable complexity had been repudiated, which Descartes himself effected on what are to us now quite tenuous grounds. I am referring to the repeated proviso Descartes makes to his rule that what an individual I can 'very clearly and very distinctly' conceive to be the case about things must in fact be the case; the proviso is that the concordance this proposes between our reasoning and a reasonably structured universe 'is assured only because God is or exists, and because he is a perfect Being' (Descartes 1968: 58, emphasis added). For it would violate God's nature as perfect for Him to deceive us on such matters. We contemporary academics have lost that divine guarantee but retain the faith in reality's legibility all the same. Which explains Lacan's otherwise obscure reference to materialists as the only true believers (2007: 66).

In this fashion I underline, with Stephen Gaukroger (1995: 321), that the Discourse from which I have been quoting is a scientifically foundational document, designed to promote acceptance of its author's Copernicanism, as much as a philosophical one. From that perspective, these are not just arguments to have any epoch, in the timeless discipline of philosophy; this is a whole episteme finding its language, contouring our possibilities right now into the present, even in the creative arts, inasmuch as they find themselves in the academy and mandated by examination policies to speak in two conflicting tongues: to produce a work of art, and to responsibilise that initial utterance as one any person in those shoes could have produced, as legitimate knowledge. From the outset it is clear that this secondary discourse is what an artist must never encumber their work with, if it is to retain the polyvocality essential to art. 
Which is why the whole package comes across as a failure at the level of editing (Magee 2014: 5). What such policies need to be changed to register is that we could be creatively reworking Foucault's (Fanon's, Clemént's, Rancière's...) approach to authority instead.

\section{A tale of two footnotes}

To show the kind of exemplary creative arts doctorate Foucault styles for us, a final contrast is in order. I am going to compare Grafton's orthodox, because autobiographical, style and Foucault's. The contrast will be stark, but not absolute. For Foucault does in fact rely, if somewhat minimally, upon these same Cartesian devices for autobiographical justification, whether in footnote or, as occurs in the passage I will be citing from, references in author-date (see further, Magee 2012b). Nor do I want to slight the subversive power of Grafton's text as an intervention into the post-structuralist debate on history and fiction, which is profound, and relies on I-cratic mechanisms to be so. Say rather that, in this overall regard, what predominates as the enduring effect of Grafton's book is something of 'the anonymity of the question' (Rajchman (1991: 6), on one of the hallmarks of Foucault's style) as well. Unfortunately, the creative arts exegesis is far harder to subordinate to that subversive end, for reasons I and others have set forth elsewhere: the problem, in brief, is in the need for artwork and exegesis to be judged as both unified and distinct, which undercuts the artistry of either (Magee 2014; Candlin 2000; Biggs \& Büchler 2010). But is an exegesis even necessary? Foucault's case suggests otherwise.

Early in The Footnote: A Curious History, Anthony Grafton jokingly refers to Herbert of Bosham, a student of the twelfth century theologian Peter of Lombard who took issue with a gloss of Peter's which had claimed that 'the Salome mentioned in the Gospel of Mark was not a woman but the third husband of St. Anne. ${ }^{60}$ (Grafton 1997: 31 sic). Grafton footnotes his mention of Bosham and Lombard thus:

60. P. Lombard, *140. For the full text see Patrologica Latina 190, 1418 B-C; for the context see B. Smalley, "A Commentary on the Hebraica by Herbert of Bosham", Recherches de théologie ancienne et medieval, 18 (1959), 29-65 at 37-40. (Grafton 1997: 31, fn.60 sic)

Now his student may well have taken Peter to account for his cross-gendering gloss, but that gloss itself was still markedly deficient as a responsibilising device, when compared to Grafton's footnote to his telling of all this. For that note lays out a veritable evidentiary trail. It implies I have been to these sources, and any other I who followed me there would see-clearly, on the face of it - that the matter (however bizarre) is as I have reported it. What we have in this footnote is a discourse of the mastering I. (For our approaches to knowledge "could not be so well organised as those who, from themoment at which they came together in association, observed the basic laws of some wise legislator,' the 'I' itself (Descartes 1968: 36)).

I turn to Foucault. Call to mind 'Discipline', Part Three of Discipline and Punish, the part which famously concludes: 'Is it surprising that prisons resemble factories, schools, barracks, hospitals, which all resemble prisons?' (Foucault 1977: 228). That Foucault's conclusion to this part of his book is an unsettling, proliferating question as much as an actual conclusion is pertinent.

But let's focus on the opening of 'Discipline', the section titled 'Docile Bodies'. We arrive at a footnote six pages in to 'Docile Bodies,' on page 141 of the Sheridan translation. Over these same 
five pages we have read that the 'classical age discovered the body as object and target of power' (Foucault 1977: 136). Foucault has also described to us an increasing concern through this epoch with the specific detail of how subjects exercised their bodies, in relation to spaces we had not previously expected to find mentioned in a book that is, after all, or at least has been to this point, on the topic of those we lock up. Yet we find mention over these five pages of the disciplinary techniques spreading through the army, schools, hospitals, industrial workshops... But my point is that this five-page discourse on bodies, exercise, detail - this discourse, in short, on discipline - culminates in the following sentence, with footnote: 'And from such trifles, no doubt, the man of modern humanism was born' (Foucault 1977: 141 sic).

My comment on interrogative propositions inhabiting the place of concluding summations could well bear repeating here (after all, one doesn't always need a question mark to ask a question). But let us turn to the footnote, which might, on the other hand, be expected to back up Foucault's provocative proposition about the origins of the man of modern humanism, and to do so in terms of its author's acquaintance with the sources any other I might inspect, so as to find that proposition responsible, or not.

In the place of any such self-justification, what we find, on turning to read the corresponding note on page 314 , is the following programmatic statement:

1. I shall choose examples from military, medical, educational and industrial institutions. Other examples might have been taken from colonisation, slavery and child rearing. (Foucault 1977: 314, fn.1 sic)

The purpose of Foucault's footnote is not the normative one Grafton incisively identifies: 'to locate the production of the work in question in time and space, emphasising the limited horizon and opportunities of its author' (1997: 31). There is no attempt autobiographically to validate the primary text's claims at all. In fact, this footnote does the opposite, claiming a knowledge much broader than that given in the text. Its purpose is hardly to render account. Is it not rather to elicit the dawning and disturbing sense from the reader that your parenting is also at stake in all this?

Which is as much to say that the accountability for whatever knowledge emerges here lies not with the authorial I, not at all. It is with the reader. Similar analyses could be advanced of the way Fanon (1970), Irigaray (1985) and Benterrak, Muecke and Roe (1984) responsibilise their own contributionsto knowledge as a problem for the reader. It is simply not necessary to engage knowledge through thecertainties of the $I$, not even at the highest institutional levels.

\section{Program}

The broader aim of this intervention has been to suggest that a creative writing doctorate might quite legitimately aim at this same space of doubt. It might, that is, eschew the scholar's typical project of justifying the primary story they tell through the provision of a secondary text that comments autobiographically on what its I has seen and done, all so as to validate the claims in the primary text, which is otherwise epistemologically indistinguishable from a novel, a poem, a story. The doctoral work might, in contrast, furnish a voice, or set of voices, from nowhere ('Leave it to our bureaucrats and our police to see that our papers are in order' [Foucault 1972: 17]), the scholarly test of which 
would be that work's capacity to elicit a certain unsettling in its examiners' intellectual and emotional grasp of the world at hand. Surely that is what Canguilhem was advocating, in labelling Foucault 'poet'.

\section{Notes}

[1] The quotation continues, 'From every academic statement by any philosophy whatsoever, even by a philosophy that strictly speaking could be pointed to as being the most opposed to philosophy, namely, if it were philosophy, Lacan's discourse - the I-cracy emerges, irreducibly' (Lacan 2007: 63). What monograph on Lacan can escape this charge?

[2] I am using FE Sutcliffe's elegant 1968 Penguin translation of the Discourse in this article. But I cite Cottingham's 1984 translation from Cambridge's The Philosophical Writings by preference in this instance, because his rendition of nous concevons (the full phrase is les choses que nous concevons très clairement et très distinctement sont toutes varies (Oeuvres philosophiques 610)) as 'we conceive' seems a better fit with Descartes' idealist position on clear and distinct ideas, than Suttcliffe's translation of the verb as 'grasp', which might well imply the use of the eyes and ears. Suttcliffe can also be reasonably taken to task for his title (it can only be Discourse on the Method) and his version of the cogito as 'I think, therefore I am' (1968: 53). As Cottingham points out (1984: 34-42, especially 34; but see also 66-73), this latter phrase fails to capture the immediacy, and indeed the ephemerality, of the certainty Descartes is going in this chapter to found his proof of God's existence - and therefore all that we know - upon. It has to be 'I am thinking, therefore I exist', as given in Cottingham's authoritative version (CSM I: 127). The burden of my argument requires me, however, to do justice, as far as possible, to Descartes' compelling style in works like the Discourse; and so I prefer Suttcliffe's in this regard more accurate renderings. The Discourse and the Meditations are, after all, works in Foucault's dizzying mould: witness the flights of doubt and even consternation that these scientifically foundational / critical / creative writings continue to elicit from the most diverse audiences (Bordo 1999: 5-6).

[3] William of Ockham (1290-1349) authored a radical, and soon widely influential, nominalist empiricism which held that we can know that two things are repeatedly associated (fire and heat for instance), but that such connections "provide no knowledge of any underlying and "real" cause ... in many cases we cannot even know if there is a cause' (Grant 1962: 203). However clearly one thought one perceived them, the causal connection between such items could never ultimately be trusted to be more than habitūs (Ockham1964: 5), habitual associations of our thinking. Similarly, a science about a given common term (eg fire) might well be possible, 'yet, properly speaking, there can be no science about the thing of which this common term is predicated' (Ockham 1964: 13). The Humean resonances of these positions have been remarked (Moody 1975: 298, 304), and indeed are striking: does not Hume also undermine our faith in fire's causal relation to heat (Hume 1978: 87)? Only to get a grasp of where things stood by the late fourteenth century we have to imagine a Humean scepticism totalised across the whole field of knowledge up to and including what we now call the sciences, a situation which is to us theoretically conceivable (Russell 2004: 647), but by the same token close to unimaginable.

\section{Works cited}

Anderson, P 2011 'The Mythologian, Review of Claude Lévi-Strauss: The poet in the laboratory', New Left Review 71 (Sept-Oct): 135-140

Ayer, AJ 1962 The problem of knowledge, Penguin, Baltimore MD

TEXT Vol 24 No 1 April 2020

General Editor: Nigel Krauth. Editors: Julienne van Loon \& Ross Watkins 
Bakhtin, MM 1981 'Discourse in the Novel', in M Holquist (ed) The dialogic imagination: four essays, University of Texas Press, Austin: 259-423

Benjamin, W 1986 Reflections: essays, aphorisms, autobiographical writing, Schocken Books, New York

Benterrak, K, S Muecke \& P Roe 1984 Reading the country: introduction to nomadology, Fremantle Arts Centre Press, Fremantle WA

Biggs, M \& D Büchler 2010 'Communities, Values, Conventions and Actions', in M Biggs \& H Karlsson (eds) The Routledge companion to research in the arts, Routledge, London: 82-97

Bordo, S (ed) 1999 Feminist interpretations of René Descartes (Re-reading the canon), Penn State University Press, University Park PA

Butler, J 2001 'What is Critique? An Essay on Foucault's Virtue', Transversal: https://transversal.at/transversal/0806/butler/en (accessed 4 April 2020)

Candlin, F 2000 'A Proper Anxiety? Practice-based PhDs and Academic Unease', Working Papers in Art and Design 1: http://journaldatabase.info/articles/proper_anxiety_practice-based_phds.html (accessed 4 April 2020)

Cartledge, P 1993 The Greeks: a portrait of self and others, Oxford University Press, Oxford

Clément, C 1988 Opera, or, the undoing of women, University of Minnesota Press, Minneapolis

Condren, C, S Gaukroger \& I Hunter (eds) 2006 The philosopher in early modern Europe: the nature of a contested identity, Cambridge University Press, Cambridge

Cottingham, J 1986 Descartes, B Blackwell, New York

de Certeau, M 1986 'The Laugh of Michel Foucault', Heterologies: discourse on the other, University of Minnesota Press, Minneapolis: 193-198

Descartes, R 1963 Oeuvres philosophiques de Descartes, Èditions Garnier Frères, Paris

Descartes, R 1968 Discourse on method; and the meditations, Penguin, Harmondsworth

Descartes, R 1984 The philosophical writings of Descartes, Cambridge University Press, Cambridge

Descartes, R 2006 Meditations, objections, and replies, Hackett Publishing, Indianapolis

Eribon, D 1991 Michel Foucault, Harvard University Press, Cambridge MA

Fanon, F 1970 Black skin, white masks, Paladin Press, St Albans UK

Fichte, H 1996 The gay critic, University of Michigan Press, Ann Arbor

Fletcher, J \& A Mann 2004 'Illuminating the Exegesis, An introduction', TEXT Special Issue Number 3: Illuminating the Exegesis, TEXT: Journal of Writing and Writing Courses 8, 1 (April): http://www.textjournal.com.au/speciss/issue3/fletchermann.htm (accessed 1 May 2020) 
Foucault, M 1972 The archaeology of knowledge, Tavistock Publications, London

Foucault, M 1977 Discipline and punish: the birth of the prison, Allen Lane, London

Foucault, M 1992 'The use of pleasure', The history of sexuality 2, Penguin, London

Foucault, M 1997 'What is Critique?,' in Michel Foucault, The Politics of Truth, ed. Sylvère

Lotringer and Lysa Hochroth, Semiotext(e), New York: 23-82

Foucault, M 2006 History of madness, Routledge, London

Frayling, C 1993 'Research in Art and Design', Royal College of Art Research Papers 1, 1: 1-5

Gaukroger, S 1995 Descartes: an intellectual biography, Clarendon Press, Oxford

Glynos, J 2002 'Psychoanalysis Operates upon the Subject of Science: Lacan between Science and Ethics', in J Glynos \& Y Stavrakis (eds) Lacan and science, Karnac, London: 51-88

Grafton, A 1997 The footnote: a curious history, Harvard University Press, Cambridge MA

Grant, E 1962 'Late Medieval Thought, Copernicus and the Scientific Revolution', Journal of the History of Ideas 23, 2: 197-220

Gross, A, J Harmon \& MS Reidy 2002 Communicating Science: The Scientific Article from the 17th Century to the Present, Oxford University Press, Oxford

Halperin, DM 1995 Saint Foucault: towards a gay hagiography, Oxford University Press, New York

Hoffmann, A 2010 Scientific writing and communication: papers, proposals and presentations,

Oxford University Press, New York

Hume, D 1978 A treatise of human nature, Clarendon Press, Oxford

Irigaray, L 1985 This sex which is not one, Cornell University Press, Ithaca NY

Jay, M 1993 Downcast eyes: the denigration of vision in twentieth-century French thought, University of California Press, Berkeley

Kant, I 2000 Critique of the power of judgment, Cambridge University Press, Cambridge

Koyré, A 1943 'Galileo and Plato', Journal of the History of Ideas 4, 4: 400-428

Lacan, J 2007 The other side of psychoanalysis, Norton, New York

Lamb, K 2005 'Foucault's Aestheticism', Diacritics 35, 2: 43-64

Lingis, A 1995 Abuses, University of California Press, Berkeley

Magee, P 2012a 'Introduction. Part 1: Beyond Accountability?', TEXT Special Issue Number 14: Beyond practice-led research, TEXT: Journal of Writing and Writing Courses 16, 2 (October): http://www.textjournal.com.au/speciss/issue14/Magee\%20(Intro\%201).pdf (accessed 1 May 2020)

Magee, P 2012b 'Poetic Fact: On Research Questions as Relations of Force', Mosaic: A Journal for 
the Interdisciplinary Study of Literature 45, 1 (March): 121-137

Magee, P 2014 'What Distinguishes Scholarship from Art?', New Writing: The International Journal for the Practice and Theory of Creative Writing 11, 3 (September): 400-416

Magee, P 2016 “"We Do not Know Exactly What We are Going to Say until We have Said it": Interview Data on how Poems are Made', New Writing: The International Journal for the Practice and Theory of Creative Writing 13, 3 (September): 434-449

Megill, A 1987 'The Reception of Foucault by Historians', Journal of the History of Ideas 48, 1 (January-March): 117-141

Moody, EA 1975 'Empiricism and Metaphysics in Medieval Philosophy', Studies in medieval philosophy, science, and logic: collected papers, 1933-1969, University of California Press, Berkeley: 287-304

Ockham, W 1964 Philosophical writings, a selection, Bobbs-Merrill, Indianapolis

Rajchman, J 1991 Truth and eros: Foucault, Lacan, and the question of ethics, Routledge, New York

Rancière, J 1991 The ignorant schoolmaster: five lessons in intellectual emancipation, Stanford University Press, Stanford

Rancière, J 2003 'Politics and Aesthetics: An Interview with Peter Hallward', Angelaki: The Journal of the Theoretical Humanities 8, 2 (August): 191-211

Russell, B 2004 History of Western philosophy, Routledge, London; New York

Strand, D 1998 Research in the creative arts, Australia Department of Employment, Education, Training and Youth Affairs, Canberra

Taussig, MT 1986 Shamanism, colonialism, and the wild man: a study in terror and healing, University of Chicago Press, Chicago

The Times Higher Education 2009 'The Most Cited Authors in the Humanities', The Times Higher Education: https://www.timeshighereducation.com/news/most-cited-authors-of-books-in-thehumanities-2007/405956.article (accessed 4 April 2020)

Valéry, P 1948 Descartes, presented by Paul Valéry, Cassell and Company, London

Walker-Bynum, C 1982 Jesus as mother: studies in the spirituality of the high middle ages, University of California Press, Los Angeles

White, HV 1973 Metahistory: the historical imagination in nineteenth-century Europe, Johns Hopkins University Press, Baltimore 